\title{
Parathyroid carcinoma presenting as hyperosmolar coma
}

\author{
J. R. Peters \\ B.Sc., M.R.C.P.
}

J. P. ThOMAS

M.D., F.R.C.P.

\author{
Department of Medicine, University Hospital of Wales, Heath Park, Cardiff
}

\begin{abstract}
Summary
A case of hyperosmolar coma is described in a patient with maturity onset diabetes, who was subsequently shown to have a parathyroid carcinoma. The pathogenesis of the hyperosmolar state is discussed.

\section{Introduction}

In their definitive account of the disorder Albright, Aub and Bauer (1934) emphasized the varied presentation of hyperparathyroidism. Relative to the nervous system, symptoms may range from confusion to fits, a frank psychosis or the features associated with an acute hypercalcaemic crisis (Pyrah, Hodgkinson and Anderson, 1966). Severe hypercalcaemia has on occasion resulted in coma and death (Paterson, 1974). In the present case, dulling of the senses was due to a hyperosmolar state in a patient with unsuspected primary hyperparathyroidism.
\end{abstract}

\section{Case report}

A 68-year-old woman with maturity onset diabetes of 5 years' duration, controlled on diet, attended the clinic because of increasing thirst, polyuria and weight loss; $8 \mathrm{~kg}$ over the previous 3 months. The blood sugar at that time was $18 \mathrm{mmol} / \mathrm{l}$. Her diet was reassessed and glipizide $5 \mathrm{mg} /$ day prescribed. Thereafter she became progressively more confused and somnolent and, on admission four days later, was unrousable.

On examination she was unconscious (grade 4) with Cheyne-Stokes respiration and markedly dehydrated. She was normotensive with no focal neurological signs. Initial investigations showed a plasma sodium of $148 \mathrm{mmol} / 1$; potassium $2.6 \mathrm{mmol} / 1$; blood urea $25.5 \mathrm{mmol} / 1$; blood glucose $20.4 \mathrm{mmol} / 1$ and osmolality $365 \mathrm{mosmol} / \mathrm{l}$. Acid base balance and blood lactate were normal.

A diagnosis of diabetic non-ketotic hyperosmolar coma was made and treatment begun with fluid replacement, insulin infusion and heparin. This resulted in a rapid fall in blood sugar, and a gradual

Correspondence: J. R. Peters, M.R.C. Unit \& Department of Clinical Pharmacology, Radcliffe Infirmary, Oxford OX2 6HE. return to full consciousness within $72 \mathrm{hr}$, although spatial disorientation persisted. At that time the serum calcium value for blood obtained on admission was reported to be $4.4 \mathrm{mmol} / 1(17.6 \mathrm{mg} / 100 \mathrm{ml})$, with a serum albumin of $23 \mathrm{~g} / \mathrm{l}$. The phosphate and alkaline phosphatase were normal. Of the standard investigations for hypercalcaemia only the serum parathyroid hormone concentration was abnormal being in excess of $10 \mathrm{ng} / \mathrm{ml}$ (normal $<1.0 \mathrm{ng} / \mathrm{ml}$ ). Plain radiology was unhelpful but a barium swallow demonstrated a constant left-sided oesophageal impression.

Following a temporary lowering of the serum calcium by means of phosphate infusion, surgical exploration of the neck was performed which revealed a lobulated encapsulated tumour, adherent to the oesophagus and surrounding the recurrent laryngeal nerve. Histology showed a highly malignant parathyroid carcinoma.

After removal of the tumour, the serum calcium concentration returned to normal and the mental faculties of the patient were restored. The diabetes was subsequently well controlled on diet alone.

\section{Discussion}

There is some evidence for an aetiological relationship between diabetes mellitus and primary hyperparathyroidism. Insulin resistance has been demonstrated in hyperparathyroidism (Kim et al., 1971) and in this context, the improvement in diabetic control of the patient postoperatively is of interest. Even though the prevalence of primary hyperparathyroidism in diabetes has been estimated at 1/1200 cases (Walsh, Soler and Malins, 1975), there would seem to be no basis for considering the coexistence of the disorders to be more than coincidental in this patient.

Although consciousness returned soon after admission, on correction of the hyperosmolar state, subsequent analysis showed that a high serum calcium persisted despite rehydration of the patient (Fig. 1). This suggested that the disturbed consciousness was a result of the hyperosmolar state and not simply of the hypercalcaemia.

The relative importance of the hyperglycaemia 


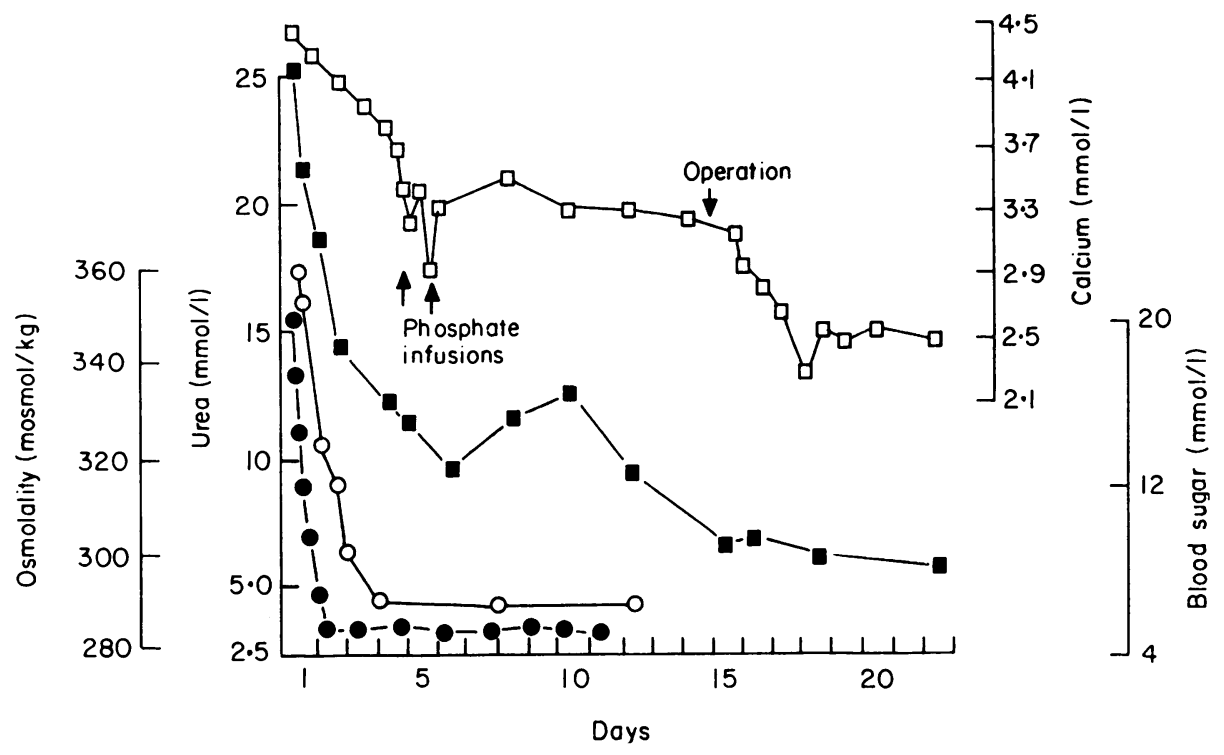

FIG. 1. Time course of biochemical changes in patient aged 68 years. $\square-\square$ Serum calcium. $\square-\square$ Blood urea. $\bigcirc-\bigcirc$ Serum osmolality. - Blood sugar.

and hypercalcaemia in the aetiology of the hyperosmolality is debatable. However, the initial blood sugar on admission was much lower than that usually seen in diabetic patients with hyperosmolality (Gerich, Martin and Recant, 1971) and, in this instance, differed little from that measured on her first attendance at the clinic when she was fully alert. Furthermore, the blood sugar returned to normal within $12 \mathrm{hr}$ of admission whilst the hyperosmolality persisted for over 3 days. The fall in osmolality was parallel to that of the blood urea, and to the initial fall in serum calcium coincidental with rehydration.

The major factor in the pathogenesis of the hyperosmolality would thus seem to have been a hypercalcaemic osmotic diuresis.

It is surmised that hypercalcaemia, due to hyperparathyroidism, induced a state of hyperosmolar coma in a mildly diabetic patient.

In retrospect, the relatively uncommon histological diagnosis (Watson, 1974) might have been predicted on the basis of the short history with acute symptoms, the lack of bony or renal manifestations and $\mathrm{e}^{-}$ unusually high concentration of parathyroid ho mone.

\section{References}

Albright, F., Aub, J.C. \& Bauer, W. (1934) Hyperpara thyroidism - a common and polymorphic condition ash illustrated by seventeen proved cases from one clinic. Journal of the American Medical Association, 102, 1276.

Gerich, J.E., Martin, M.M., \& Recant, L. (1971) Clinica and metabolic characteristics of hyperosmolar non-윽 ketotic coma. Diabetes, 20(4), 228.

Kim, H., Kalhoff, R.K., Costrini, N.U., Cerletty, J.M. \& JACOBSON, M. (1971) Plasma insulin disturbances in primary hyperparathyroidism. Journal of Clinical Investi $=$ gation, 52, 2596.

PATERSON, C.R. (1974) Metabolic Disorders of Bone. Black well Scientific Publications, Oxford.

Pyrah, L.N., Hodgkinson, A. \& Anderson, C.K. (1966) Primary hyperparathyroidism. British Journal of Surgery 53(4), 245.

Walsh, C.H., Soler, N.G. \& Malins, J.M. (1975) Diabetes mellitus and primary hyperparathyroidism. Postgraduates Medical Journal, 51, 446.

WATsON, L. (1974) Primary hyperparathyroidism. Clinics in Endocrinology and Metabolism, 3, 215. 